\title{
Pengaruh Ekstrak Kulit Buah Naga Merah (Hylocereus Polyrhizus) terhadap Waktu Perdarahan (Bleeding Time) Pada Mencit Strain Balb-C
}

(The Effect of Red Dragon Fruit (Hylocereus Polyrhizus) Peel Extract on Bleeding Time in Balb-C Strain Mice)

Dwi Mukti Kusumastuti ${ }^{1}$, Zainul Cholid², Winny Adriatmoko²

1 Fakultas Kedokteran Gigi Universitas Jember

2 Bagian Bedah Mulut Fakultas Kedokteran Gigi Universitas Jember

\begin{abstract}
Abstrak
Pencabutan gigi menyebabkan komplikasi perdarahan, sehingga tubuh merespon dengan hemostasis. Saat ini berkembang bahan alami untuk membantu proses hemostasis salah satunya adalah kulit buah naga merah yang umumnya merupakan suatu limbah. Kulit buah naga merah mengandung tanin, flavonoid dan saponin dalam menghentikan perdarahan. Tujuan penelitian untuk mengetahui pengaruh pemberian ekstrak kulit buah naga merah terhadap waktu perdarahan pada ekor mencit strain balb-C. 16 ekor mencit diadaptasikan selama satu minggu kemudian dibagi menjadi 2 kelompok (kontrol dan perlakuan). Mencit dipuasakan selama 7 jam kemudian kelompok kontrol disondase larutan $\mathrm{Na}-\mathrm{CMC}$ 0,5\% 0,5 ml. Kelompok perlakuan dibagi menjadi tiga sub-kelompok dan disondase ekstrak kulit buah naga merah dengan dosis $0,5 \mathrm{mg} / \mathrm{g}$ bb mencit, $1 \mathrm{mg} / \mathrm{g}$ bb mencit dan $1,5 \mathrm{mg} / \mathrm{g}$ bb mencit dalam $0,5 \mathrm{ml}$ larutan $\mathrm{Na}-\mathrm{CMC} 0,5 \%$. Ditunggu selama 45 menit dan dilakukan pemotongan ekor mencit $2 \mathrm{~cm}$ dari ujung ekor. Darah diteteskan pada kertas whatman yang memiliki waktu 30 detik setiap kotak. Dilakukan penghitungan banyaknya bercak darah pada kotak dan dikalikan 30 detik. Hasil penelitian didapatkan waktu perdarahan pada kelompok perlakuan dengan dosis $0,5 \mathrm{mg} / \mathrm{BB}$ mencit; $1 \mathrm{mg} / \mathrm{BB}$ mencit dan $1,5 \mathrm{mg} / \mathrm{bb}$ mencit lebih rendah secara signifikan $(p<0,05)$ dibandingkan kelompok kontrol. Kesimpulan bahwa ekstrak kulit buah naga merah (Hylocereus Polyrhizus) dapat memperpendek waktu perdarahan (bleeding time) pada mencit strain balb-c dan dosis ekstrak kulit buah naga merah (Hylocereus Polyrhizus) yang paling berpengaruh besar yaitu dosis $1 \mathrm{mg} / \mathrm{BB}$ mencit.
\end{abstract}

Kata Kunci: hemostasis, kulit buah naga merah, waktu perdarahan

\section{Abstract}

Tooth extraction causes prolonged bleeding complications and the body will respond with hemostasis. Currently developing natural medicines to help the process of hemostasis. Red dragon fruit peel, which is generally a waste containing tannins, flavonoids, and saponins to stop bleeding. Purpose was to find out the effect of red dragon fruit peel extract on bleeding time in the tail of Balb-C strain mice. 16 mice samples were adapted for one week. Mice were divided into 2 groups subsquently fasted for 7 hours. The first group as a control (0.5\% Na-CMC). The second group was given red dragon fruit peel extract which was divided into three sub-groups at a dose of $0.5 \mathrm{mg} / \mathrm{g} \mathrm{BW,} \mathrm{mg} \mathrm{/} \mathrm{g}$ $\mathrm{BW}$, and $1.5 \mathrm{mg} / \mathrm{g}$ BW. All samples were waited for 45 minutes and cut along $2 \mathrm{~cm}$ from the tip of the tail. Blood is spilled on Whatman paper which has 30 seconds in each box. The number of blood spots on the box was calculated and multiplied by 30 seconds. The result showed that bleeding time in the group given red dragon fruit peel extract was significantly lower $(p<0.05$ ) than in the control group. The conclusion was red dragon fruit peel extract (Hylocereus Polyrhizus) has an effect on shortening the bleeding time in cutting the tail of bulb-c strain mice and the dose of red dragon fruit peel extract (Hylocereus Polyrhizus) which has the most significant effect is $1 \mathrm{mg} / \mathrm{BB}$ mice.

Key words: bleeding time, hemostasis, red dragon fruit peels

Korespondensi (Correspondence) : Dwi Mukti Kusumastuti, Fakultas Kedokteran Gigi Universitas Jember. Jalan Kalimantan No.37, Kampus Tegal Boto, Jember, Jawa Timur 68121, Indonesia. Email: kusumastutidwimukti@gmail.com

Di Indonesia pemanfaatan pelayanan kesehatan gigi dan mulut untuk pencabutan gigi sangat tinggi yaitu mencapai $79,6 \%$. $^{1}$ Pencabutan gigi dapat menyebabkan perlukaan jaringan sehingga timbul perdarahan.2 Saat terjadi luka, tubuh memiliki mekanisme untuk mengembalikan komponenkomponen jaringan yang rusak dengan membentuk struktur baru dan fungsional. Proses penyembuhan luka dibagi ke dalam beberapa tahap, meliputi tahap hemostasis, inflamasi, proliferasi, dan remodeling jaringan. ${ }^{3}$

Perdarahan merupakan suatu hal yang wajar dengan waktu perdarahan normal pasca pencabutan gigi, akan berhenti 3-4 menit. ${ }^{4}$ Prevalensi komplikasi perdarahan setelah pencabutan gigi di Departemen Bedah Mulut Tokyo Women's Medical University sebesar $8,1 \% .^{5}$ Resiko komplikasi perdarahan dapat terjadi karena faktor lokal, seperti lepasnya ikatan pembuluh darah setelah operasi dan faktor sistemik yang terjadi pada penderita dengan kelainan sistemik seperti gangguan koagulasi.6 Oleh sebab itu, pencapaian dari proses hemostasis sangat diperlukan. Hemostasis adalah suatu mekanisme pertahanan tubuh dalam menghentikan perdarahan yang terbagi dalam tiga tahap, yaitu kontriksi pembuluh darah, pembentukan trombosit, dan koagulasi. ${ }^{7}$ Proses hemostasis dapat dipengaruhi dengan pemberian obat yang dapat mempercepat waktu perdarahan, seperti epinefrin sebagai vasokonstriktor akan tetapi memiliki efek samping yaitu dapat mempengaruhi sirkulasi sistemik. ${ }^{8}$

Untuk meminimalkan efek samping dari obat-obatan hemostatik yang mungkin terjadi, maka diperlukan bahan alami pengganti yang memiliki khasiat hemostasis. Senyawa utama yang berperan dalam menghentikan perdarahan adalah tanin, flavonoid dan 
saponin.9 Tanin dan saponin dapat mempercepat keluarnya protein dari sel dan mengendapkan protein darah, sehingga dapat menginduksi sintesis tromboksan A2 dan serotonin. 9 Tromboksan A2 dan serotonin memiliki fungsi sebagai vasokonstriktor sehingga aliran darah menjadi berkurang ${ }^{8}$. Selain itu, tromboksan A2 juga dapat meningkatkan agregasi trombosit, sehingga mempercepat pembentukkan jendalan darah. ${ }^{10}$ Selain tanin dan saponin, adanya senyawa flavonoid dapat memperkuat dinding pembuluh darah kapiler dan mengurangi terjadinya hiperpermeabilitas dinding pembuluh darah (edema), sehingga perdarahan yang timbul akan terhenti. ${ }^{3}$

Salah satu tanaman yang mengandung tannin, flavonoid dan saponin terdapat dalam kulit buah naga merah (Hylocereus polyrhizus). Kulit buah naga merah memiliki kandungan antara lain flavonoid, tanin, alkaloid, steroid, vitamin C, dan saponin. ${ }^{11}$ Kandungan tanin dan flavonoid pada gel ekstrak kulit buah naga merah memiliki efek dapat mempercepat penyembuhan luka. ${ }^{12}$ Penelitian lain menyebutkan bahwa ekstrak kulit buah naga merah dapat menurunkan kadar interleukin-6 dengan dosis optimal sebesar $1 \mathrm{mg} / \mathrm{g}$ bb mencit yang diberikan secara per oral.13 Oleh sebab itu kulit buah naga merah dapat berpotensi besar dalam menghentikan perdarahan. Berdasarkan uraian diatas, maka peneliti tertarik untuk menguji pengaruh ekstrak kulit buah naga merah terhadap waktu perdarahan pada mencit strain balb-C, yang dilukai pada bagian ekornya dengan dosis $0,5 \mathrm{mg} / \mathrm{g} B \mathrm{~B}$ mencit, $1 \mathrm{mg} / \mathrm{g} B B$ mencit, $1,5 \mathrm{mg} / \mathrm{g} \mathrm{BB}$ mencit secara per oral. Waktu perdarahan normal pada luka ekor mencit terjadi selama 8 menit dengan waktu pembekuan darah antara 2-10 menit. 8,14

\section{METODE PENELITIAN}

Jenis penelitian ini adalah penelitian eksperimen laboratories dengan rancangan penelitian the post test only control group design. Penelitian ini dilaksanakan di Laboratorium Biomedik Fakultas Kedokteran Gigi Universitas Jember yang sebelumnya dilakukan pengurusan Ethical Clearance untuk subjek penelitian hewan di Komisi Etik Penelitian Kesehatan Fakultas Kedokteran Gigi Universitas Jember dan identifikasi tanaman buah naga merah (Hylocereus polyrhizus) di Fakultas Matematika dan IImu Pengetahuan Alam. Sampel yang digunakan sebanyak 16 ekor mencit strain balb-C yang dibagi menjadi 2 kelompok, yaitu kelompok kontrol (K) dan perlakuan (P). Pada kelompok kontrol (K) hanya di sondekan Na-CMC 0,5\% sebanyak $0,5 \mathrm{ml} / \mathrm{bb}$. Sedangkan pada kelompok perlakuan dibagi menjadi tiga sub-kelompok dan diberikan ekstrak kulit buah naga merah dengan dosis $0,5 \mathrm{mg} / \mathrm{g}$ bb mencit (P1), $1 \mathrm{mg} /$ $\mathrm{g}$ bb mencit (P2) dan $1,5 \mathrm{mg} / \mathrm{g}$ bb mencit (P3) secara per oral dalam $0,5 \%$ Na-CMC sebanyak
$0,5 \mathrm{ml} / \mathrm{bb}$ mencit. Semua sampel dilakukan pemotongan pada ekor mencit sepanjang 0,5 $\mathrm{cm}$ dari ujung ekor mencit. Darah diteteskan pada kertas serap setiap 30 menit sampai perdarahan berhenti. Setelah itu waktu perdarahan dihitung dan dianalisis.

Data waktu perdarahan kemudian dianalisis menggunakan software SPSS stastistic. Dilakukan uji normalitas Shapiro-Wilk, uji homogenitas menggunakan Levene test. Hasil analisis menunjukkan data berdistribusi normal namun tidak homogen sehingga diasumsikan tidak memenuhi uji normalitas. Data dilanjutkan dengan uji non parametrik Kruskal Wallis dan Mann-Whitney U.

\section{HASIL}

Berdasarkan penelitian yang telah dilakukan, didapatkan rata-rata nilai waktu pendarahan pada kelompok K (kontrol), Pl (ekstrak kulit buah naga merah dosis $0,5 \mathrm{mg} / \mathrm{bb}$ mencit), P2 (ekstrak kulit buah naga merah dosis $1 \mathrm{mg} / \mathrm{bb}$ mencit), P3 (ekstrak kulit buah naga merah dosis $1,5 \mathrm{mg} / \mathrm{bb}$ mencit) yang ditampilkan pada Tabel 1 dibawah ini.

Tabel 1. Rata-rata nilai waktu perdarahan pada mencit strain balb/c dengan ekstrak kulit buah naga merah dosis $0,5 \mathrm{mg} / \mathrm{bb}$ mencit, $1 \mathrm{mg} / \mathrm{bb}$ mencit $1,5 \mathrm{mg} / \mathrm{bb}$ mencit dan Na-CMC 0,5\%.

\begin{tabular}{ccc}
\hline Kelompok & N & Rata-rata \\
\hline K & 4 & 480 detik \\
P1 & 4 & 270 detik \\
P2 & 4 & 195 detik \\
P3 & 4 & 345 detik \\
\hline
\end{tabular}

$\mathrm{N}$, jumlah sampel; $\mathrm{K}$, kelompok kontrol negative dengan Na-CMC 0,5\%; $\mathrm{Pl}$, kelompok perlakuan ekstrak kulit buah naga merah dosis $0,5 \mathrm{mg} / \mathrm{bb}$ mencit; P2, kelompok perlakuan ekstrak kulit buah naga merah dosis $1 \mathrm{mg} / \mathrm{bb}$ mencit; P3, kelompok perlakuan ekstrak kulit buahnaga merah dosis 1,5 $\mathrm{mg} / \mathrm{bb}$ mencit

Tabel 1 menunjukkan bahwa waktu perdarahan pada kelompok perlakuan $(P)$ lebih cepat berhenti dibandingan dengan waktu perdarahan pada kelompok kontrol (K) dan terjadi penurunan waktu perdarahan seiring bertambahnya dosis yang dibuktikan pada kelompok P2 memiliki rata-rata waktu perdarahan lebih rendah dibandingankan dengan kelompok P1. Namun, rata-rata waktu perdarahan meningkat kembali pada dosis yang lebih tinggi yaitu kelompok P3.

Data yang diperoleh kemudian diuji normalitasnya dengan uji Shapiro-Wilk dan didapatkan hasil bahwa data tidak berdistribusi normal dengan nilai signifikansi $(p)<0,05$. Analisis data kemudian dilanjutkan dengan uji homogenitas dengan uji Levene dan didapatkan hasil bahwa data tidak homogen dengan nilai signifikansi $(p)<0,05$. Data yang tidak terdistribusi normal dan homogen maka diasumsikan dengan menggunakan uji Kruskal Wallis. Hasil uji Kruskal Wallis menunjukkan signifikansi $(p)<0,05$ yang artinya terdapat perbedaan waktu 
perdarahan dari semua kelompok maka dilanjutkan dengan uji lanjutan yaitu ManWhitney $U$ yang menunjukkan bahwa terdapat perbedaan yang signifikan pada beberapa kelompok penelitian dengan nilai signifikasi (p) $<0,05$ dikarenakan ada perbedaan nilai yang signifikan dari kelompok $\mathrm{K}$ dan kelompok P. Pemberian ekstrak kulit buah naga merah pada kelompok $\mathrm{Pl}$ yang lebih tinggi dibandingkan kelompok P2. Sedangkan, pemberian ekstrak kulit buah naga merah pada kelompok P3 memiki rata-rata waktu perdarahan yang lebih panjang dibandingkan kelompok P2.

\section{PEMBAHASAN}

Hasil penelitian yang didapat menunjukkan bahwa waktu perdarahan pada kelompok perlakuan $(\mathrm{P})$ dibandingan dengan waktu perdarahan pada kelompok kontrol (K). Hal tersebut dikarenakan pada kelompok kontrol hanya diberikan Na-CMC 0,5\% yang tidak mempengaruhi proses hemostasis fisiologis mencit. Sedangkan pada kelompok perlakuan waktu perdarahan dipengaruhi oleh adanya zat aktif seperti tanin, saponin dan flavonoid yang terkandung dalam ekstrak kulit buah naga merah, dimana ketiga zat tersebut merupakan senyawa utama yang diduga dapat membantu mempercepat proses hemostasis.

Tanin berkerja sebagai vasokonstriktor melalui efek astringennya yang dapat mengurangi permeabilitas kapiler, kontraksi ruang antar sel, pengerasan endothelium kapiler dan membentuk lapisan pelindung sehingga lapisan superfisial sel akan mengencang dan menyusut yang akan menghasilkan vasokontriksi lokal kapiler. ${ }^{8}$ Tanin juga dapat mempercepat keluarnya protein sehingga dapat menginduksi sintesis tromboksan A2 dan serotonin. Serotonin dan tromboksan A2 memiliki fungsi sebagai vasokonstriktor kuat, selain itu tromboksan A2 juga berfungsi dalam proses aktivasi trombosit yang saling berdekatan yang akan menyebabkan terjadinya agregasi trombosit. Adanya agregasi trombosit pada daerah luka menyebabkan terhentinya perdarahan..$^{15}$

Adanya zat lain seperti flavonoid diduga bekerja secara sinergis dengan tanin dalam mempercepat waktu perdarahan. Flavonoid merupakan senyawa fenol yang terdapat hamper semua tumbuhan.16 Flavonoid berperan dalam menjaga permeabilitas serta meningkatkan resistensi pembuluh darah kapiler dan bekerja pada endotelium mikrovaskular untuk mengurangi terjadinya hiperpermeabilitas dan edem. ${ }^{17}$ Flavonoid juga dapat meningkatkan fungsi endotel dengan menurunkan tekanan oksidatif. ${ }^{18}$ Salah satu peran flavonoid lainnya adalah menekan prostasiklin yang merupakan vasodilatator dan penghambat agregasi trombosit. ${ }^{19}$ Apabila prostasiklin dihambat, maka agregasi trombosit akan terbentuk lebih banyak sehingga waktu perdarahan akan memendek jika dibandingkan dengan waktu perdarahan normal.

Waktu perdarahan yang memendek juga dipengaruhi adanya zat saponin yang memiliki sifat mengendapkan sel darah sehingga dapat menginduksi sintesis tromboksan A2 dan serotonin untuk beragregasi lebih cepat yang akan menyebabkan terhentinya perdarahan. ${ }^{20}$

Pemberian ekstrak kulit buah naga merah pada kelompok $\mathrm{Pl}$ yang lebih tinggi dibandingkan kelompok P2 dimungkinkan karena jumlah prostasiklin maupun tromboksan A2 yang dihambat masih dalam jumlah yang minimal sehingga dimungkinkan adanya dosis $0,5 \mathrm{mg} / \mathrm{bb}$ mencit ini belum dapat merusak jalur siklooksigenase secara maksimal yang menyebabkan prostasiklin dapat cepat pulih, adanya produksi prostasiklin ini menyebabkan pemanjangan waktu perdarahan ${ }^{10}$. Sedangkan, pemberian ekstrak kulit buah naga merah pada kelompok P3 dengan dosis $1,5 \mathrm{mg} / \mathrm{bb}$ mencit memiki rata-rata waktu perdarahan yang lebih panjang dibandingkan kelompok P2 dengan dosis esktrak kulit buah naga $1 \mathrm{mg} / \mathrm{bb}$ mencit. Hal tersebut dimungkinkan adanya peningkatan kepekatan dari larutan pada dosis tinggi sehingga efek flavonoid akan menurun'2. Tingkat kepekatan larutan yang terlalu tinggi dapat menghambat saponin untuk menembus membran sel sehingga keefektifan dari ekstrak kulit buah naga dosis $1,5 \mathrm{mg} / \mathrm{bb}$ mencit akan menurun. ${ }^{21}$

Ekstrak kulit buah naga merah (Hylocereus Polyrhizus) dapat berpengaruh dalam memperpendek waktu perdarahan (bleeding time) pada pemotongan ekor mencit strain balb-c dimana dosis ekstrak kulit buah naga merah (Hylocereus Polyrhizus) yang berpengaruh besar dalam memperpendek waktu perdarahan adalah dosis $1 \mathrm{mg} / \mathrm{bb}$ mencit.

\section{DAFTAR PUSTAKA}

1. Agtini M. Persentase Pengguna Protesa Di Indonesia. Media Heal Res Dev. 2010; 20(2): 50-8.

2. Rahman KM, Amir D, Noer M. Efek Pencabutan Gigi terhadap Peningkatan Tekanan Darah pada Pasien Hipertensi. J Kesehat Andalas. 2017; 6(1): 61.

3. Putri RR, Hakim RF, Rezeki S. Pengaruh Ekstrak Daun Tapak Dara (Catharanthus Roseus) Terhadap Jumlah Fibroblas Pada Proses Penyembuhan Luka Di Mukosa Oral. J Caninus Denstistry. 2017; 2(1): 2030.

4. Gavali M, Singru S, Gavali Y, Preeya M, Krishnakant P. Comparision of BT (Bleeding Time) / CT (Clotting Time) with Respect to Blood Group in Medical Students. Int J Heal Sci Res ISSN 2249-9571. 2017; 7(1): 57-63. 
5. Kataoka T, Hoshi K, Ando T. Is The HASBLED Score Useful In Predicting PostExtraction Bleeding In Patients Taking Warfarin? A Retrospective Cohort Study. BMJ Open. 2016; 6(3).

6. Vitria EE. Evaluasi Dan Penatalaksanaan Pasien Medically-Compromised $\mathrm{Di}$ Tempat Praktek Gigi. J Dentomaxillofacial Sci. 2011 ; 10(1): 47-52.

7. Kainde AR, Pangemanan DHC, Hutagalung BSP. Uji Efektivitas Ekstrak Daun Sendok (Plantago Major L.) Terhadap Waktu Perdarahan Pada Tikus Wistar Jantan (Rattus Norvegicus). eGIGI. 2016; 4(2): 271-6.

8. Tedjasulaksana R. Ekstrak Etil Asetat dan Etanol Daun Sirih (Piper betle L.) dapat Memperpendek Waktu Pendarahan Mencit (Mus Musculus). J Kesehat Gigi. 2013; 1(1): 32-9.

9. Arisa Gaib, Lisa; Rahayu, Muji; Sukeksi A. Pengaruh Ekstrak Daun Gedi Kering ( Abelmoschus manihot L . Medik ) terhadap Waktu Pembekuan Darah secara In Vitro Menggunakan. Prosiding. 2019; 2(2): 238-41.

10. Astuti P. Peranan Asetosal Sebagai AntiTrombotik Terhadap Metabolisme Tromboksan A2 (TXA2) Dan Prostasiklin (PGI2). Stomatognatic. 2010; 7(1): 51-5.

11. Noor Ml, Yufita E, Zulfalina. Identifikasi Kandungan Ekstrak Kulit Buah Naga Merah Menggunakan Fourier Transform Infrared ( FTIR ) Dan Fitokimia. J Aceh Phys Soc [Internet]. 2016; 5(1): 14-6. Available from:

http://www.jurnal.unsyiah.ac.id/JAcPS

12. Andhini rofillah putri. Efek Ekstrak Kulit Buah Naga Merah (Hylocereus Polyrhizus) Terhadap Jumlah Sel Fibroblas Pada Soket Gigi Tikus Wistar. Surabaya: Fakultas Kedokteran Gigi Universitas Airlangga; 2016.
13. Puspitasari S, Hendarto $H$, widjiati. Pengaruh Ekstrak Kulit Buah Naga Merah (Hylocereus Polyrhizus) Terhadap Kadar Interleukin-6 Mencit Model Endometriosis. Biosains Pascasarj. 2017; 19(03): 92-6.

14. Nugroho R. Mengenal Mencit Mebagai Hewan Laboraturium. Samarinda: Mulawarman University Press; 2018. 195 p.

15. Sutopo T, Bestari RS, Sintowati R. Uji Ekstrak Etanol 70\% Daun Sirih (Piper Betle L.) Terhadap Bleeding Time Pada Mencit Jantan Galur Swiss Webster. Biomedika. 2017; 8(2): 2-8.

16. Wulan A, Dharmayanti S, Apriono DK, Biomedik B, Kedokteran F, Universitas $G$. Pengaruh Pemberian Infusum Daun Salam (Eugenia polyantha W) Pada Eksresi Asam Urat Tikus Wistar Jantan. Stomatognatic. 2012; 9(3): 165-7.

17. Kurniawati A. The Effectiveness Of Cacao Bean Extract Toward Tooth Extraction Healing On Macrophages. Dent J Kedokt gigi. 2019; 13(2): 49-57.

18. Jawi M. Ekstrak Air Umbi Ubi Jalar Ungu Menurunkan Tekanan Darah Tikus Putih Hipertensi Yang Diinduksi Dengan Nacl. Medicina (B Aires). 2012; 43(1): 72-6.

19. Athiroh ASN, Permatasari N. Mekanisme Kerja Benalu Teh pada Pembuluh Darah Mechanism of Tea Mistletoe Action on Blood Vessels. J Kedokt Brawijaya. 2012; 27(1): 1-7.

20. Pattewar S V. Kalanchoe Pinnata: Phytochemical And Pharmacological Profile. Int J Phytopharm. 2012; 1 (2): 1-8.

21. Sucita RE, Hamid IS, Fikri F, Purnama MTE. Ekstrak Etanol Kayu Secang (Caesalpinia sappan L.) Secara Topikal Efektif pada Kepadatan Kolagen Masa Penyembuhan Luka Insisi Tikus Putih. J Med Vet. 2019; 2(2): 119. 